\title{
HOME RANGES AND MOVEMENT PATTERNS OF THE MARINE TUCUXI DOLPHIN, SOTALIA FLUVIATILIS, IN BAÍA NORTE, SOUTHERN BRAZIL
}

\author{
Paulo A. C. Flores ${ }^{1,2, *}$ and Mariel Bazzalo ${ }^{2}$
}

\begin{abstract}
Marine tucuxi dolphins (Sotalia fluviatilis) studied in Baía Norte, southern Brazil, exhibited very small overall home ranges with daylight movements in consistent water depths of around $3 \mathrm{~m}$. Mean overall home range areas calculated through two methodologies were similar, measuring $13.38 \mathrm{~km}^{2} \pm 1.92$ using the Minimum Convex Polygon method and $15.22 \mathrm{~km}^{2} \pm 0.66$ through the kernel estimator. Mean core areas calculated by kernel were extremely small [mean $=1.49 \mathrm{~km}^{2}$ at $50 \%$ UD (utilization distribution) and $0.87 \mathrm{~km}^{2}$ at $25 \%$ UD levels]. The geographical distributions of home ranges and core areas overlapped extensively at both 50\% UD and 25\% UD. Daylight movements ranged from 0.16 to $28.97 \mathrm{~km} /$ day (mean $=5.65 \pm 0.56 \mathrm{~km} /$ day, SD $=5.36$ ) with mean minimum rate of movement of $2.6 \pm 0.2 \mathrm{~km} / \mathrm{h}(\mathrm{SD}=2.02)$. Daylight movement patterns varied seasonally with higher values of distance moved and rate of movement in winter and winter and autumn, respectively. The marine tucuxi home ranges and daylight movement patterns presented here are smaller than much of what is known for other coastal small cetaceans. The percentage of overall home range within the limits of a protected area designated for the tucuxis could be considered moderate to high depending on the estimator used $\left(54.06 \%\right.$ or $5.9 \mathrm{~km}^{2}$ by MCP and $74.71 \%$ or $11.35 \mathrm{~km}^{2}$ using the kernel). Nevertheless, core areas are completely within the protected area. Conservation implications of these findings include the need to: $(i)$ create a buffer zone to the south of the existing protected area which will encompass the overall home range of the tucuxis; (ii) establish constant, adequate enforcement of fishery and boat traffic regulations in the core areas; and (iii) regulate boat traffic and aquaculture farming in important areas which are not yet subject to specific regulations.
\end{abstract}

Resumo - Tucuxis marinhos (Sotalia fluviatilis) estudados na Baía Norte, sul do Brasil, apresentaram áreas de vida bastante pequenas com movimentos diurnos em profundidades constantes próximas de $3 \mathrm{~m}$. A média das áreas de vida geral calculadas através de dois métodos foram similares, medindo $13.38 \mathrm{~km}^{2} \pm 1.92$ usando o Mínimo Polígono Convexo e $15.22 \mathrm{~km}{ }^{2} \pm 0.66$ pelo estimador kernel. A média das áreas de vida principais calculadas pelo método kernel foram extremamente pequenas (média $=$ $1.49 \mathrm{~km}^{2}$ a $50 \%$ UD e apenas $0.87 \mathrm{~km}^{2}$ a $25 \%$ UD (níveis de utilização de distribuição)). Houve intensa sobreposição da distribuição geográfica das áreas de vida gerais e principais tanto aos níveis de 50\% UD quanto de $25 \%$ UD. Os movimentos diurnos variaram de 0.16 a $28.97 \mathrm{~km} /$ dia (média $=5.65 \pm 0.56 \mathrm{~km} / \mathrm{dia}, \mathrm{DP}=5.36) \mathrm{com}$ taxa mínima de movimento média de $2.6 \pm 0.2 \mathrm{~km} / \mathrm{h}(\mathrm{DP}=$ 2.02). Os padrões de movimentos diários variaram sazonalmente sendo os maiores valores de distância percorrida e taxa de movimento encontrados no inverno e no inverno e outono, respectivamente. Os valores de áreas de vida e movimentos diurnos apresentados são menores do que muitos dos valores conhecidos para outros pequenos cetáceos costeiros. A porcentagem das áreas de vida geral dentro dos limites marinhos da unidade de conservação criada para proteger os tucuxis marinhos no local pode ser considerada moderada a alta, dependendo do estimador de área de vida considerado (54.06\% ou $5.9 \mathrm{~km}^{2}$ pelo Mínimo Polígono Cconvexo e $74.71 \%$ ou $11.35 \mathrm{~km}^{2}$ usando o kernel). De qualquer forma, ás áreas de vida principais estão completamente dentro da unidade de conservação. Implicações para a conservação dessa espécie na área de estudo incluem a necessidade de: (i) criar um zona tampão ou de amortecimento ao sul dos atuais limites da unidade conservação, de forma a incluir toda a área de vida dos tucuxis marinhos; (ii) estabelecer uma fiscalização adequada e constante da pesca e do tráfego de embarcações nas áreas de vida principais dos tucuxis; e (iii) regulamentar o tráfego de embarcações e a maricultura em áreas importantes ainda não sujeitas a legislação e regulamentação específicas.

Keywords: marine tucuxi, Sotalia fluviatilis, home range, movement patterns, southern Brazil, conservation.

\section{Introduction}

Home range is an important ecological aspect of an animal population and it has been broadly considered as "... that area traversed by the individual in its normal activities of food gathering, mating, and caring for young. Occasional sallies outside the area, perhaps exploratory in nature, should not be considered as part of the home range" (Burt, 1943). Home range size is an important ecological feature, as it is indicative of the space required by an animal to meet its needs under a given set of constraints, including resource availability. The minimum area polygon (also known as the minimum convex polygon or MCP hereafter) is maybe the most widely used and simplest method to measure home range size. It is obtained by constructing a convex polygon which connects the outer locations of an animal distribution (see Jenrich and Turner, 1969 and also reviews in Garrot and White, 1990). Alternatively, for performing statistical analyses, the concept of 'utilization distribution' has been applied which expresses the relative amount of time or location points that an animal spends or had in any place over time (e.g., see Hayne, 1949; Jenrich and Turner, 1969; Van Winkle, 1975). The kernel estimator is one the best methods for estimating the 'utilization distribution' by means of nonparametric statistics (e.g., reviewed in Silverman, 1986 and Worton, 1987). Many other methods have been developed since then, but the MCP and the kernel remain the most popular and comparable approaches (see reviews in Van Winkle, 1975; Worton, 1987 and White and Garrot, 1990).

Home ranges of the tucuxi (Sotalia fluviatilis) have not been reported previously and its movement patterns have been only scarcely assessed (Da Silva and Best, 1996; Flores, 2002). Marine tucuxi daily movements entering and leaving some localities were assessed without calculating or presenting values of distance or speed traveled (Andrade et al. 1987; Geise 1991; Oliveira et al. 1995; Geise et al. 1999). Because of its distribution in the coastal waters of South and Central America, the marine ecotype of the species is threatened from a variety of human induced sources such as habitat

\footnotetext{
${ }^{1}$ PUCRS, Laboratório de Dinâmica Populacional, Instituto de Biociências. Av. Ipiranga, 6681, Porto Alegre, RS 90619-900 Brazil. ${ }^{2}$ International Wildlife Coalition/Brasil, C.P. 5087, Florianópolis, SC 88040-970 Brazil.

* Current address: International Wildlife Coalition/Brasil, C.P. 5087, Florianópolis, SC 88040-970 Brazil. E-mail: flores.p@terra.com.br
} 
loss, pollution, fish stock depletion and mainly by incidental catches (Da Silva and Best, 1996; Flores, 2002). Thus, baseline information on its ecology, including data on home ranges and movement patterns is important for conservation.

In Baía Norte, southern Brazil, the austral limit of distribution for the species, the marine tucuxi (Sotalia fluviatilis) has been studied over the last 12 years (e.g., Flores, $1992 ; 1999 ; 2003)$. This paper examines the movements and home ranges of dolphins over a seven-year study period. Conservation implications regarding the studied population are also discussed in the light of legal protection given to this population by Brazilian federal laws.

\section{Material and Methods}

\section{Study area}

Baía Norte and surrounding waters $\left(27^{\circ} 23^{\prime}-27^{\circ} 35^{\prime} S, 48^{\circ} 33^{\prime}\right.$ $-48^{\circ} 30^{\prime} \mathrm{W}$ ), located on the southern Brazilian coast (Figure 1 ), are very shallow with depths usually less than $12 \mathrm{~m}$, except at the North channel (around 14m) and the strait connecting to South Bay (more than $25 \mathrm{~m}$ ). These coasts are a mosaic of Atlantic Rain Forest remnants, sand beaches, rocky shores, small salt marshes, mangroves and urban developments mainly in and around Florianópolis city to the southern part of the bay.

Three species of small cetaceans have been sighted in Baía Norte. The marine tucuxi is found year round almost on a daily basis and over long term periods ( $>10$ years) in a resident, small population which has been studied since the early 1990s (Flores, 1999; 2003). The bottlenose dolphin (Tursiops truncatus) is much less frequent (Flores 2003) and the franciscana (Pontoporia blainvillei) is rarely sighted in the study area, being seen only twice during 1993 to 1997 (Flores et al., 2000).

Potential predators for the marine tucuxi have been recorded in Baía Norte or nearby. A $\sim 1.70 \mathrm{~m}$ tiger shark (Galeocerdo cuvieri) was caught in a gillnet on July 2001 (identified by photographs of the fresh animal) near Ratones Is., Baía Norte, about $5 \mathrm{~km}$ from the tucuxis' area of distribution (P.A.C. Flores, pers. obs.). An established shark fishery targeted at various species including the bull shark (Carcharhinus leucas) takes place near the Arvoredo Archipelago (e.g., CEPSUL - IBAMA 1998; UNIVALI 2001, 2002). During austral summer 2001 a group of about eight orcas (Orcinus orca) including two adult males were seen

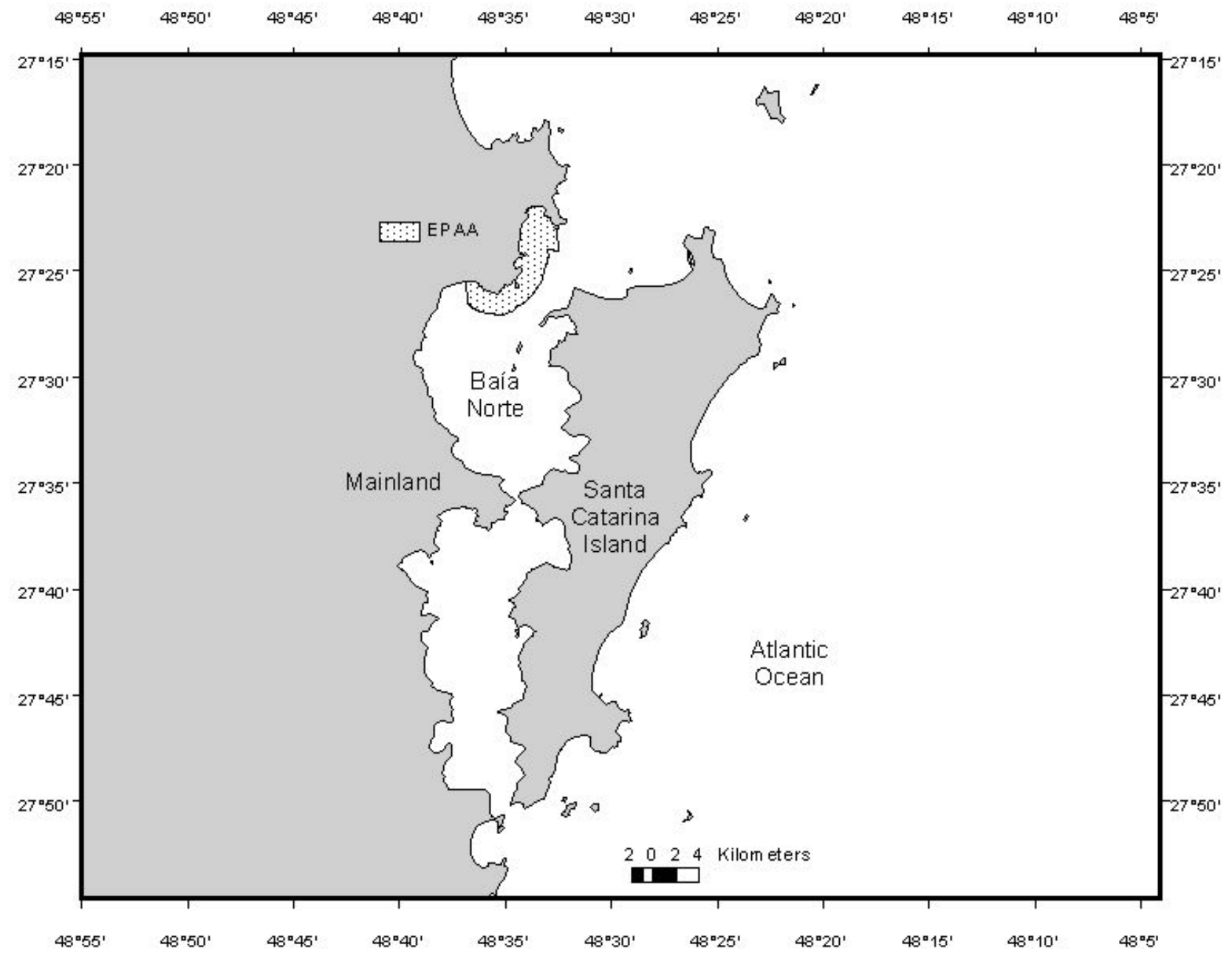

Figure 1. Study site showing the maritime boundaries of the Environmental Protection Area of Anhatomirim (dotted area). 
and filmed also near Arvoredo Archipelago (footage provided by José Luís, Schooner Vento Sul, Florianópolis, SC). This archipelago is located about $25 \mathrm{~km}$ northeast of the tucuxis' home range. A stranded orca was recorded in 1979 about $100 \mathrm{~km}$ north the study area (Bittencourt, 1983) and an adult male was sighted on May 1991 off Laguna, Sta. Catarina (Simões-Lopes and Ximenez, 1993) some $120 \mathrm{~km}$ south of Baía Norte.

The Environmental Protection Area of Anhatomirim (EPAA) is a multiple-use conservation unit created by Brazilian Federal Decree \# 528 of 20 May 1992 with "the main purpose to ensure protection to the wild resident population of the marine dolphin Sotalia fluviatilis and its feeding and breeding areas". It is located in the northwestern continental part of Baía Norte (Figure 1), comprising 4,750-ha from which approximately 3,090-ha is marine waters. Later specific regulations were applied to tourism boat traffic in a small sector of the EPAA (Directive 58-N of January 1998).

\section{Field procedure}

Descriptions of boat based surveys and observation sampling of the marine tucuxi in Baía Norte have been provided by Flores (1999). Using a small inflatable boat (5m, 30hp four stroke outboard engine since 1996) surveys have been conducted throughout the study area. Boat based work was conducted up to 5 days/week and no more than one survey was undertaken in a given day. Some days were dedicated to systematic surveys while others combined surveys, photo-identification, and behavioral observations. Because sea conditions may deteriorate after noon, the time spent engaged in the surveys varied.

Two types of surveys were conducted, always without following a regular, established course: focal group survey and "random survey". During focal-group surveys the same animals are observed and usually photographed until the end of the survey. "Random surveys" are conducted when survey effort is resumed after leaving a sighting. This may occur when: (i) it is concluded that most individuals were photographed, (ii) the initial $5 \mathrm{~min}$. of sampling is obtained, and/or (iii) weather or sea state conditions are poor or deteriorating. In all three cases, surveys were usually resumed after a dolphin sighting to increase chances of having other sightings in the same survey. Once a group of dolphins was encountered, environmental variables were measured at the initial dolphin sighting location and then dolphin data were determined and recorded at 5 minute intervals. Dolphin data included time of day, location of dolphins, number of individuals in the group, group composition (adult, juvenile, calf, female), behavioral activity, and birds in association during feeding behavior. Photographic identification then was started whenever appropriate.

Photographs were taken with a 70-300-mm (f 4.0-5.6) zoom lens mounted on a $35 \mathrm{~mm}$ camera equipped with a motorized film winder. A variety of film was used (Kodak Plus-X 125 ASA black and white, Kodak T-Max 400 ASA black and white, Ektachrome 64 ASA slide, Fujichrome
Provia 100 ASA slide, Fujicolor 200 and 400 color print) but mostly ISO 400 black and white. As many animals as possible were photographed in each sighting. Individuals were identified primarily from scars, notches and marks on the dorsal fins, but also secondarily from distinctive scars and marks on the flanks and head. Photographic identification effort (or photographs taken) was not evenly distributed during the study (Flores, 1999, 2003). Sighting locations were determined through both nautical charts ( $\mathrm{n}^{\circ} 1903$ of the Division of Hydrography and Navigation, Brazilian Navy) and by a Global Positioning System (GPS) handheld device.

\section{Definitions}

The encounter with either a group or solitary animals during the course of a survey was defined as a 'sighting' and thus represents the sampling unit. A group of dolphins refers to an aggregation of dolphins within visual range of the survey team and usually engaged in the same general activity or behavior pattern. A group may contain individuals of all age classes.

Seasons were defined by the Austral calendar as follows: Autumn, 21 March - 20 June; Winter, 21 June - 20 September; Spring, 21 September - 20 December; Summer, 21 December - 20 March.

A tucuxi was defined as an adult female if a calf accompanied it on at least five consecutive sightings. "Probable male" was defined as any large animal heavily scarred and with no calf in any photograph taken, similarly to what has been described for bottlenose dolphins by Smolker et al. (1992) and Tolley et al. (1995), recognizing that these assumptions have not been tested for tucuxi, and may lead to incorrect gender assignations.

\section{Data analysis}

Data from sightings from 1996 to 2002 were used for home range estimates while data including both sighting locations as well as focal group sampling during 2001 and 2002 has been used in movement assessment.

Home ranges were calculated using the MCP and the kernel estimator, both methods subtracting any landmasses. Through the Kernel estimator were calculated the home range or overall ranging area (95\% utilization distribution - UD) and the core area at two different levels (50\% UD and 25\% UD). Typically, a reliable estimation of home range is obtained with 100 or more locations (Samuel and Fuller, 1996) and this has proven to be the case in Atlantic bottlenose dolphins T. truncatus in Sarasota, USA (Owen et al. 2002). One way of defining how many locations are required is to plot home range area versus sequentially obtained locations until the home range size reaches an asymptote (Harris et al., 1990). This was applied to our data set and the asymptote was reached at around 30 locations using the MCP while for the kernel estimator the curve did not clearly stabilize (Figure 2). Therefore, to calculate marine tucuxi home ranges we used only the thirteen individuals with the largest photographic records (ranging 


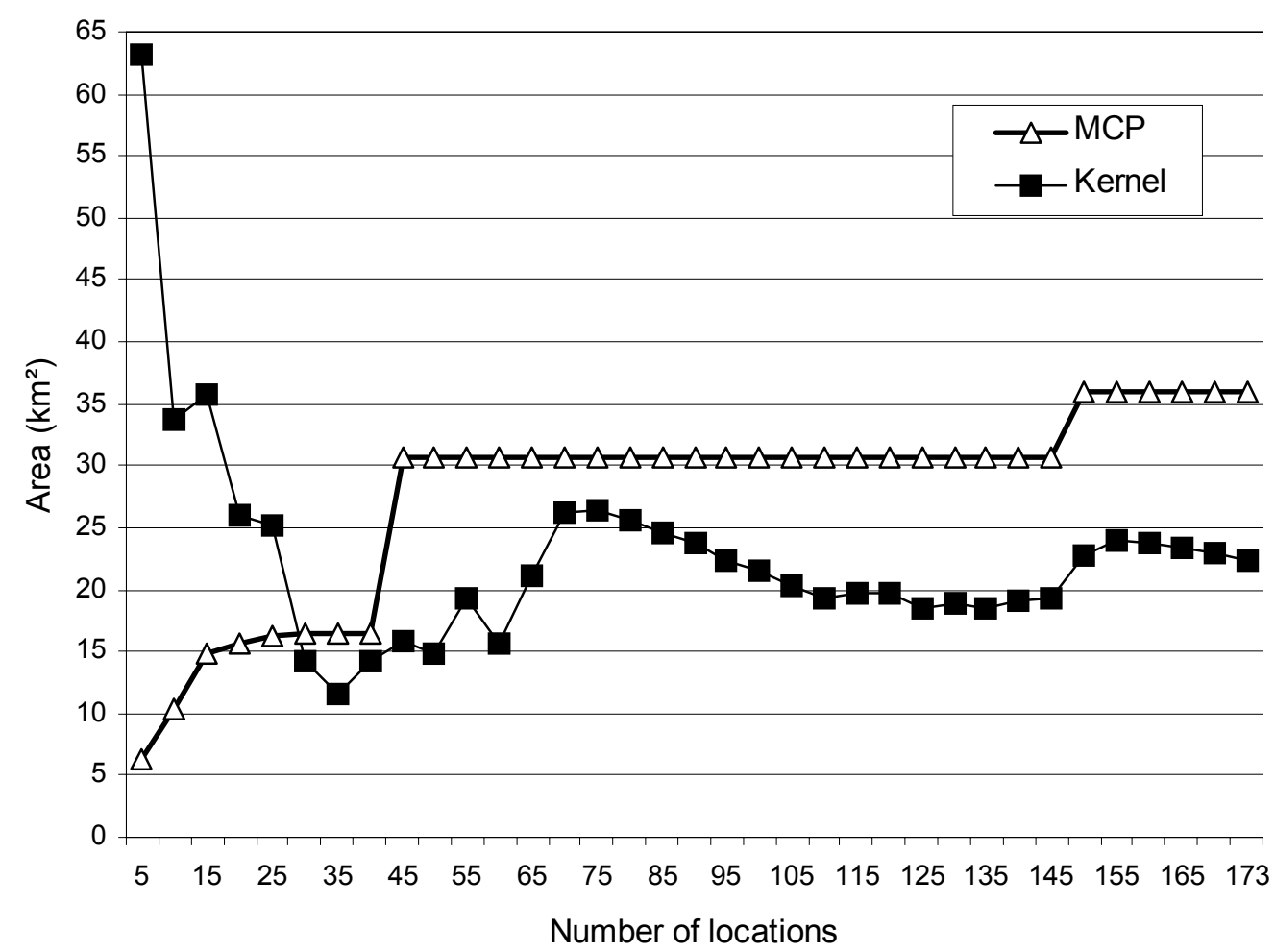

Figure 2. Accumulated curve of home range area by sequentially collected sighting locations of identified marine tucuxi (Sotalia fluviatilis) in Baía Norte, southern Brazil, during 1996 to 2002.

from 33 to 53 locations out of the 173 group sightings obtained for 1996-2002). Gender assignation of these individuals was evenly distributed.

Dolphins \#A05, B04, C04, D01 and T'sM are presumed females, dolphins \#D02, 'Parceiro', 'Dude', 'Caroço' and 'Narizota' were classified as 'probable males', while individuals \#A06 and SB (Shark Bite) were not assigned gender. Dolphin 'Tippy' was a calf and later a juvenile during the study and no gender was assigned. Seven adult individuals (dolphins \#A05, A06, B04, Tippy's Mom or T'sM, C04, D01 and D02) were photographed every year since 1996, one adult was seen since 1997 (SB). Two adults ('Parceiro' and 'Dude') were recorded from 2000 to 2002 and two other adults ('Caroço' and 'Narizota') only during 2001 and 2002. One individual ('Tippy') first identified as a calf of female T'sM in 2000 was sighted from 2000 to 2002, including after leaving its mother in July 2002 and has become a juvenile.

Daylight distance moved was calculated by measuring the straight, shortest distances of subsequent GPS readings every five minutes throughout a focal group sampling from the first to the last time of each dolphin sighting (always avoiding land masses). Daylight rate of movement was estimated by dividing the total distance moved during a given day by the total time of direct observations of dolphins (focal group sampling).

The mean focal sampling time or direct observation for the movement pattern assessment was 2:16h $(\mathrm{SD}=1: 10)$ and was evenly distributed throughout the seasons (Kruskal-
Wallis $P=0.582, \mathrm{H}=1.9542$ ). Dolphins were observed from 6:30AM to 5:00PM.

Movements were calculated on a daily basis and then combined and compared by season and between years.

Home range and movements were calculated through ArcView 3.1 with the help of the extensions Spatial Analyst 1.1 and Animal Movement 2. Statistical analysis was performed using BioEstat 2.0. Differences in home ranges from the two estimators as well as among genders through the two methods were tested with Mann-Whitney U tests at $P<0.05$ (Zar, 1999). Movements were tested among seasons through the Kruskal-Wallis and between years using the Mann-Whitney $U$ tests at $P<0.05$ (Zar, 1999).

\section{Results}

Home ranges

The mean overall home range area was $13.38 \mathrm{~km}^{2} \pm 1.92 \mathrm{using}$ the MCP. The mean kernel home range at $95 \%$ UD was $15.22 \mathrm{~km}^{2} \pm 0.66$ and the core areas were $1.49 \mathrm{~km}^{2}$ at $50 \%$ UD and $0.87 \mathrm{~km}^{2}$ at $25 \%$ UD levels. Home ranges varied from 5.39 to $21.57 \mathrm{~km}^{2}$ by MCP and 12.59 to $19.57 \mathrm{~km}^{2}$ through kernel (Table 1). Overall home ranges did not differ between the two methods employed (Mann-Whitney $U$ test, $P=0.898$ ).

There was an extensive, almost complete overlap in home ranges for all individuals through both methods, including the core areas at both the 50\% and 25\% UD (Figures 3-9). Overall kernel home ranges were split in two areas for nine 
Table 1. Home ranges of individuals calculated by the minimum convex polygon (MCP) and the kernel estimator as overall at the 95\% UD (Utilization Distribution) and core areas at the 50\% and 25\% UD.

\begin{tabular}{|c|c|c|c|c|c|}
\hline INDIVIDUALS & $\begin{array}{l}\text { PRESUMED } \\
\text { GENDER }\end{array}$ & $\mathrm{MCP}$ & $\begin{array}{c}\text { KERNEL AT } \\
95 \% \text { UD }\end{array}$ & $\begin{array}{c}\text { KERNEL AT } \\
50 \% \text { UD }\end{array}$ & $\begin{array}{l}\text { KERNEL AT } \\
25 \% \text { UD }\end{array}$ \\
\hline A05 & 우 & 7.21 & 17.17 & 1.47 & 0.87 \\
\hline A06 & & 20.15 & 16.06 & 1.25 & 0.84 \\
\hline B04 & 우 & 21.57 & 15.97 & 1.58 & 0.94 \\
\hline Tippy & & 17.64 & 14.09 & 1.52 & 0.92 \\
\hline T'sM & 우 & 15.17 & 13.57 & 1.58 & 0.94 \\
\hline SB & & 19.75 & 17.72 & 1.77 & 1.03 \\
\hline C04 & 우 & 20.06 & 19.57 & 1.73 & 0.95 \\
\hline D01 & 우 & 7.52 & 13.28 & 1.59 & 0.79 \\
\hline D02 & $\sigma^{\prime \prime}$ & 21.19 & 18.39 & 1.76 & 0.95 \\
\hline Parceiro & $\sigma^{\prime \prime}$ & 6.85 & 13.35 & 1.39 & 0.8 \\
\hline Dude & $0^{\prime}$ & 6.03 & 12.59 & 1.26 & 0.74 \\
\hline Caroço & $0^{\prime}$ & 5.39 & 12.75 & 1.24 & 0.74 \\
\hline Narizota & $0^{\circ}$ & 5.39 & 13.35 & 1.29 & 0.77 \\
\hline Mean & & 13.39 & 15.22 & 1.49 & 0.87 \\
\hline SE & & 1.92 & 0.66 & 0.05 & 0.03 \\
\hline
\end{tabular}

individuals (Figures 3-9). These were two females (\#A05 and D01 - Figures 3-4), the calf/juvenile ('Tippy' - Figure 5), all five 'probable males' (\#D02,'Parceiro', 'Dude', 'Caroço' and 'Narizota' - Figures 6-8), and an adult with no gender assignment (SB - Figure 9).

Home ranges of females were larger than of 'probable males', both through the MCP (females mean $=14.31 \mathrm{~km}^{2} \pm 3$; probable males mean $=8.97 \mathrm{~km}^{2} \pm 3.1$ ) and the kernel (females mean $=15.91 \mathrm{~km}^{2} \pm 1.2$; probable males mean $=14.09 \mathrm{~km}^{2} \pm$ 1.1). However, no significant differences were found between females and 'probable males' using both methods (MannWhitney $U$ test, $P=0.0758$ for $\mathrm{MCP}$ and $P=0.1745$ for kernel). The mean area of home ranges within the limits of the EPAA was $5.9 \mathrm{~km}^{2}(54.06 \%$ of overall home range) by MCP and $11.35 \mathrm{~km}^{2}(74.71 \%)$ through the kernel estimator (Table 1). Both the $50 \%$ and $25 \%$ UD core areas of kernel estimator were completely within the EPAA for all individuals (Figures 3-9).

\section{Movement patterns}

Daily distances moved ranged from $0.16 \mathrm{~km}$ to $28.97 \mathrm{~km} /$ day $($ mean $=5.65 \mathrm{~km} \pm 0.56, \mathrm{SD}=5.36 \mathrm{~km})$ and were not significantly different (Mann-Whitney U test, $P=0.327$ ) between years (year 2001 mean $=6.73 \mathrm{~km} \pm 1.36, \mathrm{SD}=6.5 \mathrm{~km}$ and 2002 mean $=5.29 \mathrm{~km} \pm 0.59, \mathrm{SD}=4.91 \mathrm{~km})$. However, distance moved differed among seasons (Kruskal-Wallis, $P=0.0429)$. On average, tucuxi dolphins moved almost twice as far in autumn (mean $=6.69 \mathrm{~km}, \mathrm{SD}=5.41$ ) and winter (mean $=6.49 \mathrm{~km}, \mathrm{SD}=5.21)$ than in summer $($ mean $=3.72 \mathrm{~km}, \mathrm{SD} 4.7)$ and such differences were statistically significant (Tukey test, $P=0.0116$ for summer and autumn, $P=0.0266$ for summer and winter). Mean distance moved by tucuxis in spring was $5.01 \mathrm{~km}(\mathrm{SD}=5.67)$ with no significant differences for the other seasons.

The mean overall rate of movement did not vary significantly from year to year, with an overall rate of $2.63 \mathrm{~km} / \mathrm{h} \pm 0.21(\mathrm{SD}=2.02), 2.86 \mathrm{~km} / \mathrm{h} \pm 0.54(\mathrm{SD}=2.59)$ in 2001, and $2.56 \mathrm{~km} / \mathrm{h} \pm 0.22(\mathrm{SD}=1.82)$ in 2002 (MannWhitney $\mathrm{U}$ test, $P=0.950)$. Rate of movement differed through the seasons, however (summer: mean $=1.38 \mathrm{~km}$, $\mathrm{SD}=1.32$; spring: mean $=2.33 \mathrm{~km}, \mathrm{SD}=1.84$; autumn: mean $=2.56 \mathrm{~km}, \mathrm{SD}=1.30$; winter: mean $=2.93 \mathrm{~km}, \mathrm{SD}=1.54$; Kruskal-Wallis test, $P=0.0018$ ). Differences were statistically significant (Tukey test) between summer and autumn $(P=0.0063)$, summer and winter $(P=0.0002)$ as well as winter and spring $(P=0.0219)$.

Movement patterns clearly followed the 3-m depth contour in the western sector of the bay (Figure 10), regardless of distance moved, rate of movement or season. Deeper water movement was rare and limited to $5 \mathrm{~m}$, except for two excursions over 8-10m deep waters in winter and spring. Similarly, they moved to the eastern bay sector only twice, during winter (Figure 10). All 60-80 individuals in the sighted group performed these extreme movements.

\section{Discussion}

\section{Home ranges}

No significant differences were found between home range sizes using the MCP and the kernel methods for 13 individual marine tucuxis in Baía Norte. However, MCP values varied more (5.39 to $21.57 \mathrm{~km}^{2}$ ) than those from kernel $\left(12.59\right.$ to $\left.19.57 \mathrm{~km}^{2}\right)$ and such variation is likely to result from the intrinsic definitions of each method and 
the different periods of time in which individuals were seen. For example, nine dolphins have the kernel home range areas split into two polygons because of the density of locations in the core areas. The calculated areas of these home ranges were clearly smaller than the actual values thereby biasing the mean area at the $95 \%$ UD $\left(15.22 \mathrm{~km}^{2} \pm 0.66\right)$ which would be a little higher. Nevertheless, the maximum values were very similar in each method $\left(21.57 \mathrm{~km}^{2}\right.$ with MCP and $19.57 \mathrm{~km}^{2}$ by kernel). It would be at least conservative then to recognize that an appropriate mean value of home range area would stand between the means found (MCP mean $=13.38 \mathrm{~km}^{2}$ and kernel mean $=15.22 \mathrm{~km}^{2}$ ).

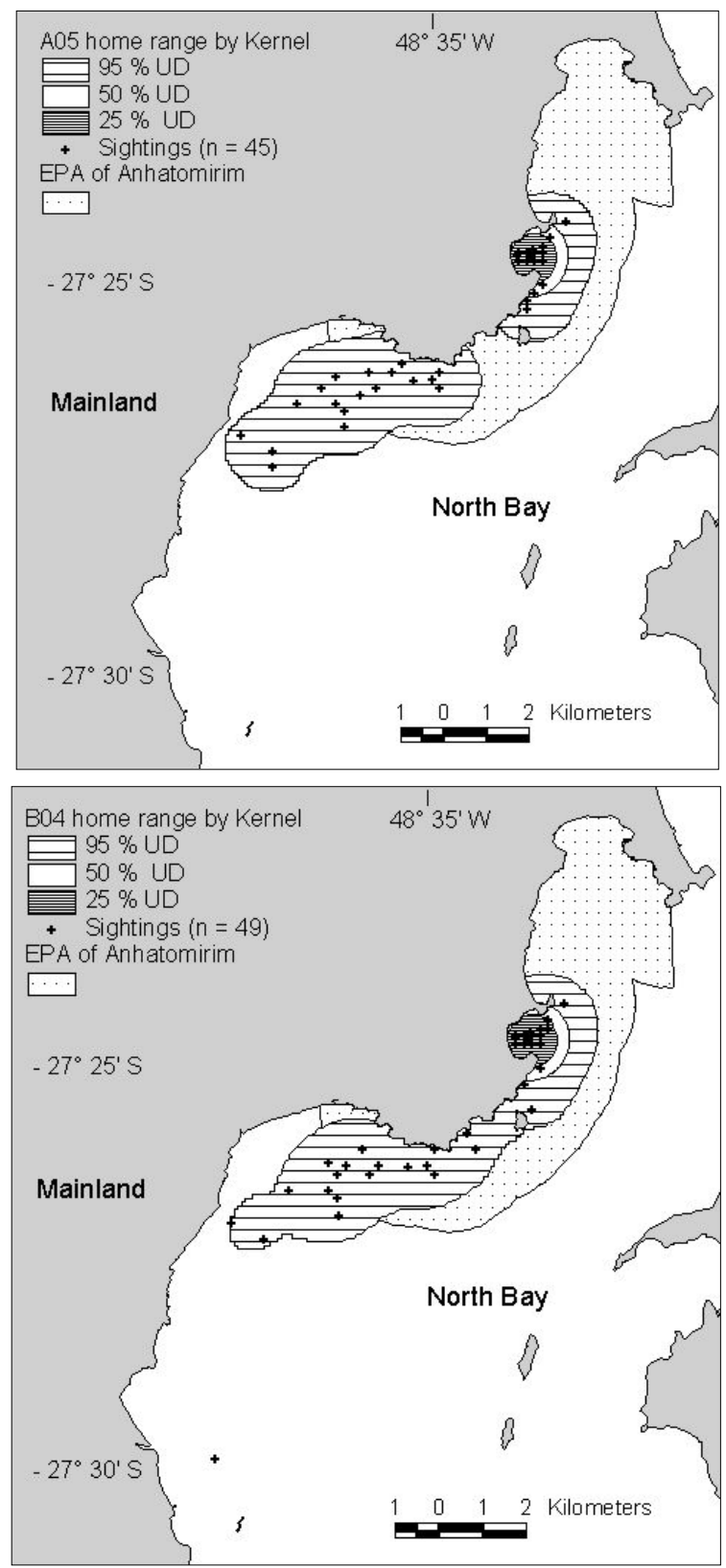

Though its weaknesses are widely recognized, the MCP estimator is still being used and remains one of the most commonly applied techniques because of the validity for comparison to previous studies and its ease of calculation (Samuel and Fuller, 1996; Seaman et al., 1999). The kernel density estimator is considered one of the best methods, though yet not applied to many studies (Seaman and Powell, 1996). However, as stated by these authors, as computer programs become more widely available and easy to use, there has been an increased interest in and utilization of the kernel estimator. Having data from both estimators would then facilitate comparisons of the results of this study to others. Furthermore, it would help compare

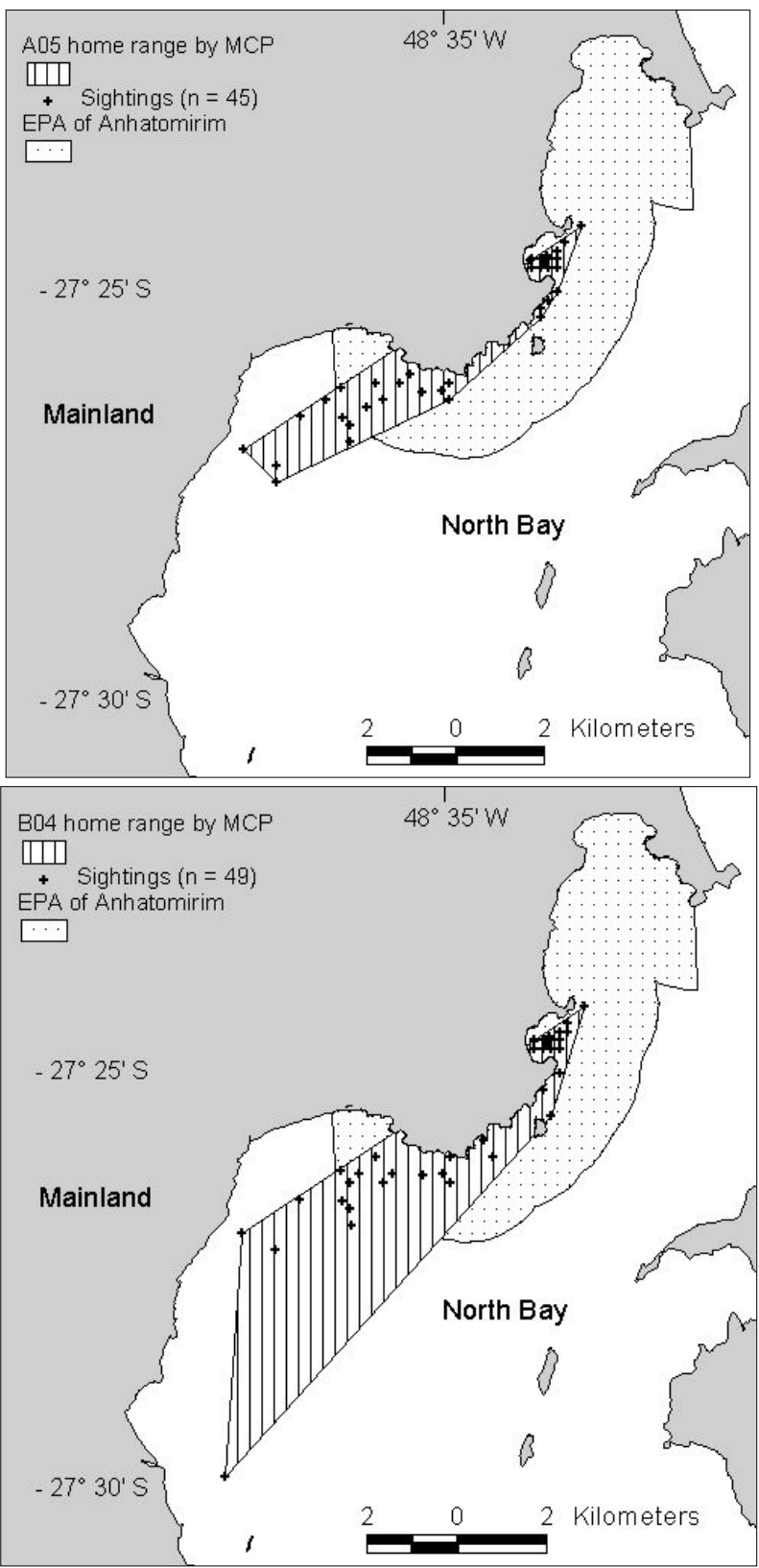

Figure 3. Home ranges of two presumed female marine tucuxis (\#A05 - top, and B04 - bottom) in Baía Norte, southern Brazil, calculated by the kernel (left) and the minimum convex polygon (MCP - right) methods. 
between methods and decide which would be better suitable to the study case.

Home range estimates of marine tucuxi in Baía Norte reported here are likely to represent actual values as the studied population has been shown to have a very discrete, restricted distribution pattern, based on a larger data set collected over 10ys (Flores, 1999; 2003). Additionally, this population ranges over a small area of about $40 \mathrm{~km}^{2}$ (Bazzalo and Flores, in preparation). In spite of the fact that other tucuxis have been studied within $200 \mathrm{~km}$ north of Baía Norte (Cremer, 2000), none of the dolphins identified in Baía Norte have been identified at any other tucuxi research site.

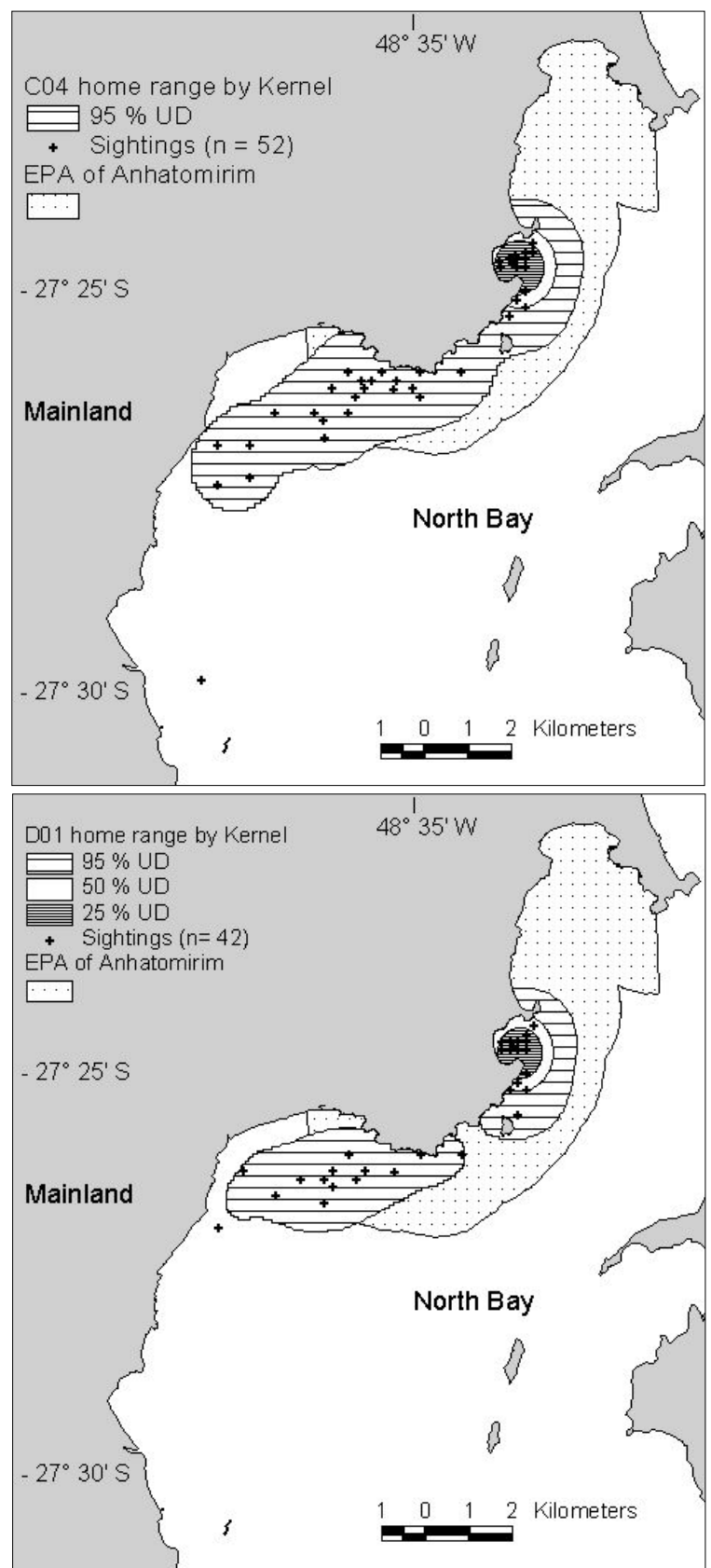

The marine tucuxi overall home range, as well as the core areas at both levels 50 and 25\% UD are extremely small when compared to those of other small cetaceans. Home ranges in small cetaceans vary in size and such differences are considered to be a function of various factors including body size, physiological requirements, habitat heterogeneity and predation pressure (e.g., see reviews in Connor, 2000 and also Forcada, 2002). Coastal bottlenose dolphins in Sarasota, Florida, have mean overall ranges of $162.58 \pm 24.21 \mathrm{~km}^{2}$ and cores areas of $28.74 \pm 9.17 \mathrm{~km}^{2}$ at $50 \%$ and $9.30 \pm 3.06 \mathrm{~km}^{2}$ at $25 \%$ UD levels (Owen et al., 2002). Home ranges of 27 Indo-Pacific humpback dolphins (Sousa

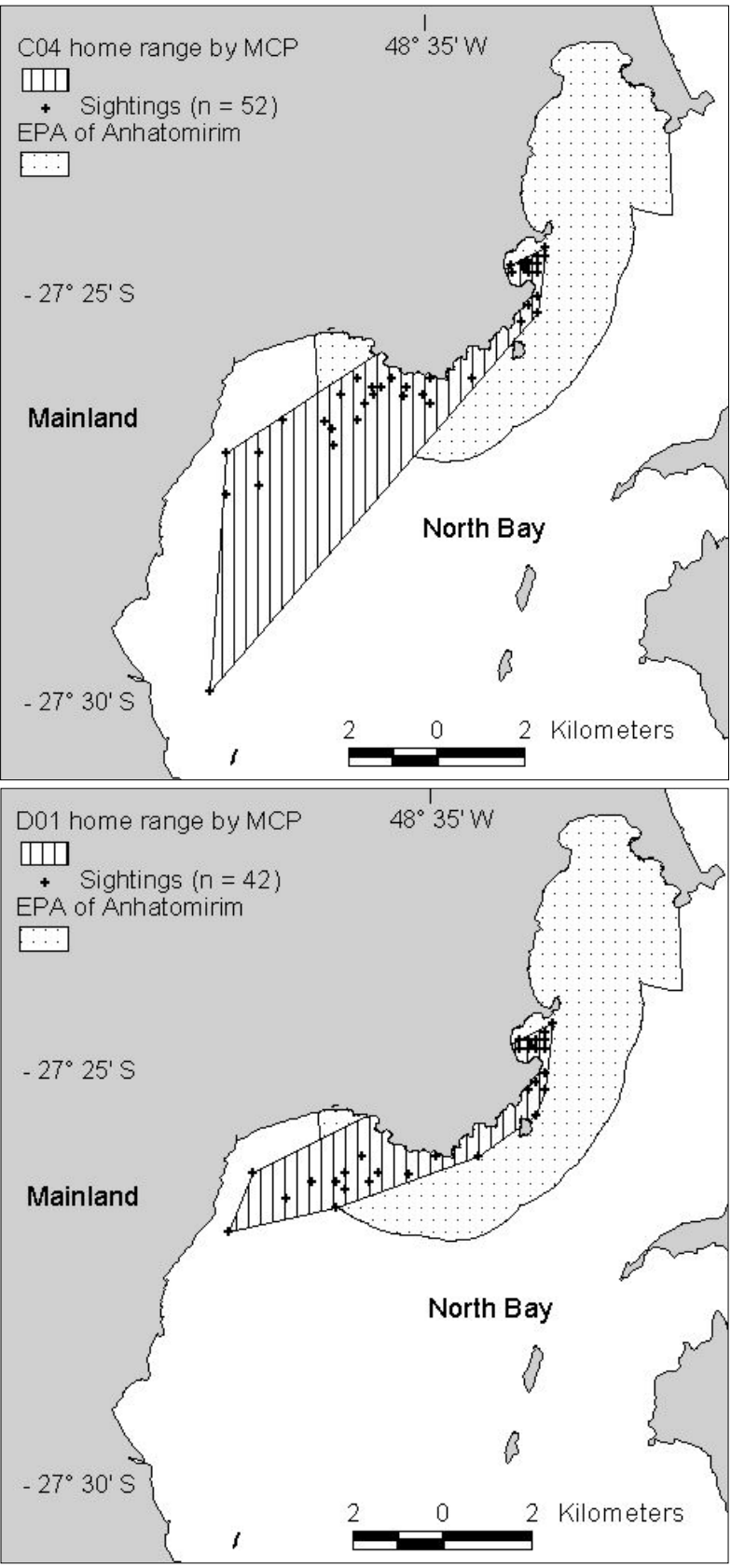

Figure 4. Home ranges of two presumed female marine tucuxis (\#C04 - top, and D01 - bottom) in Baía Norte, southern Brazil, calculated by the kernel (left) and the minimum convex polygon (MCP - right) methods. 
chinensis) ranged from 24 to $304 \mathrm{~km}^{2}$ in Hong Kong and Pearl River Estuary (Hung and Jefferson, 2004).

Mangroves are key components of very productive ecosystems, which support high concentrations of nutrients, zooplankton, fishes and other fauna (Cintrón and Schaeffer-Novelli, 1983). Over 185 species of 60 different families of fishes are found in Brazilian mangroves (Avelline, 1980). Several of these fishes, such as the white mullet (Mugil curema), the southern anchovy (Lycengraulis grossidens), the Atlantic cutlass fish (Trichiurus lepturus) and the whitemouth croaker (Micropogonias furnieri), among others, are prey items of the marine tucuxi in Baía Norte (Emerim, 1994) and elsewhere (Borobia and Barros, 1989;
Di Beneditto, 2000; Santos et al., 2002; Santos and Haimovici, 2001; Zanelatto, 2001). Baía Norte coastline has four mangroves where several of these prey items have been recorded, including white mullets, southern anchovies, Atlantic cutlass and whitemouth croaker fishes (e.g., Clezar et al., 1998; Marcon, 2000). Most of these fish species are found year round as juveniles in different total lengths, thus indicating that these mangroves are important nursery grounds (e.g., Clezar et al., 1998; Hostim-Silva et al., 1998; Ribeiro et al., 1998; Marcon, 2000). This also suggests these mangroves are important suppliers of food resources, which would sustain this dolphin population, but nothing is known of the specific fish communities in
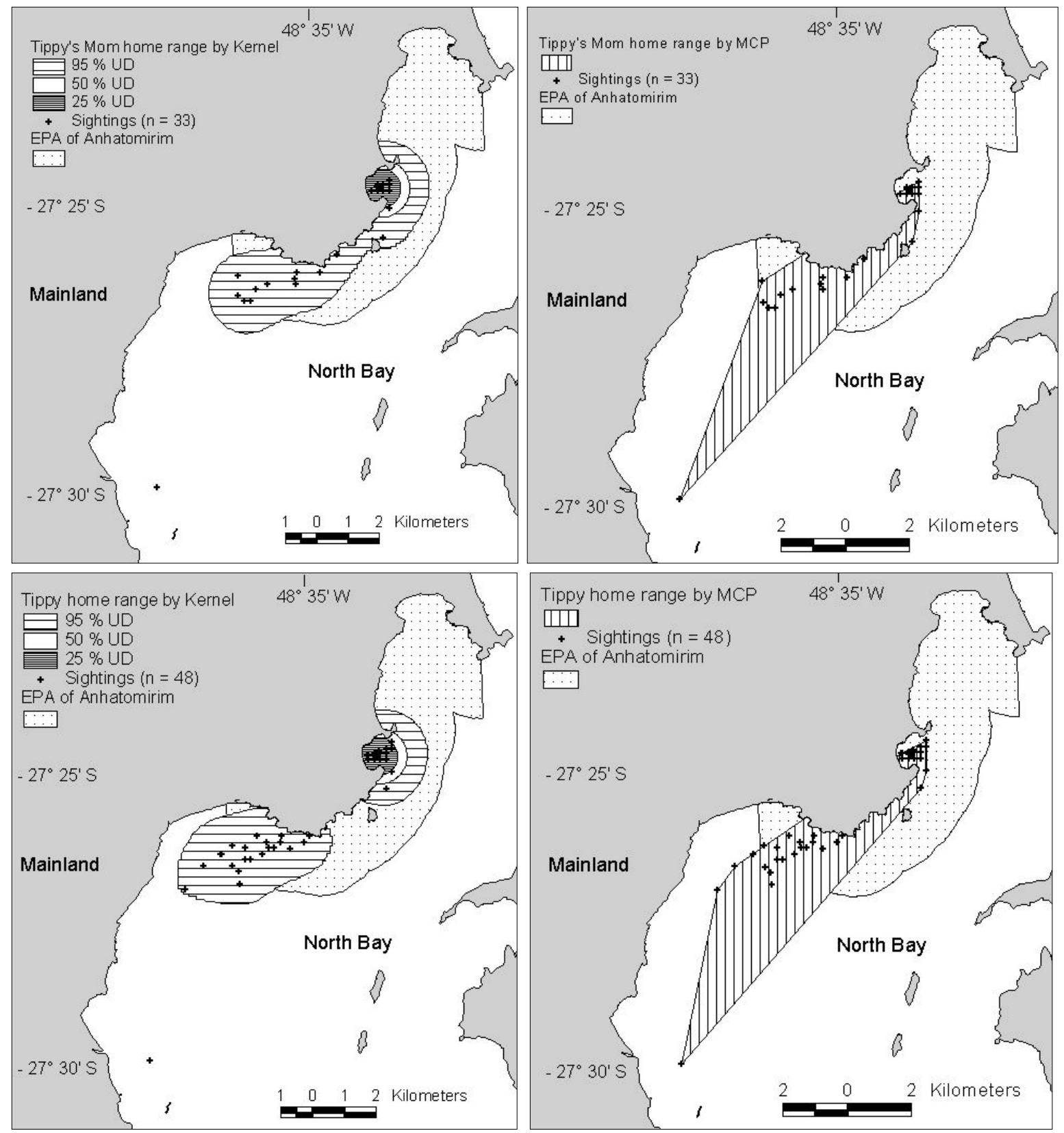

Figure 5. Home ranges of a presumed female ('Tippy's Mom' or \#T'sM - top) and its calf/juvenile ('Tippy' - bottom) marine tucuxis in Baía Norte, southern Brazil, calculated by the kernel (left) and the minimum convex polygon (MCP - right) methods. 
the bay area. Such studies are needed to contribute to a better understanding of the home range size in marine tucuxis in Baía Norte.

The similarity in size and overlap in areas of home ranges of all individuals including females, 'probable males', a calf/juvenile and the two individuals not assigned gender are interesting. Such traits are characteristic of rare cetacean populations living in productive systems and forming stable groups, such as the orcas in British Columbia, Canada (e.g., Bigg et al., 1990; Ford et al., 1994). As group dynamic analyses unfold, a similar stability of the marine tucuxi in Baía Norte is being revealed with long-term residency and site fidelity (Flores, 2003), as well as stable associations both in the short and long term (Flores, unpublished). Recent findings of a closed population of bottlenose dolphins living in low-productivity systems show an unprecedented stability (Lusseau et al., 2003) and the ecological constraints which shape marine tucuxi home range, movements and social structure in Baía Norte need to be fully investigated (Flores, 2003).

From the 13 individuals discussed here, three (\#A05, A06 and C04) have been seen in the area since 1993, while another three animals (\#B04, D01 and D02) have been present from 1994 onwards (Flores, 1999; 2003). They as well as other individuals are year round and long-term residents of a very well-defined, small area with high degrees of site fidelity
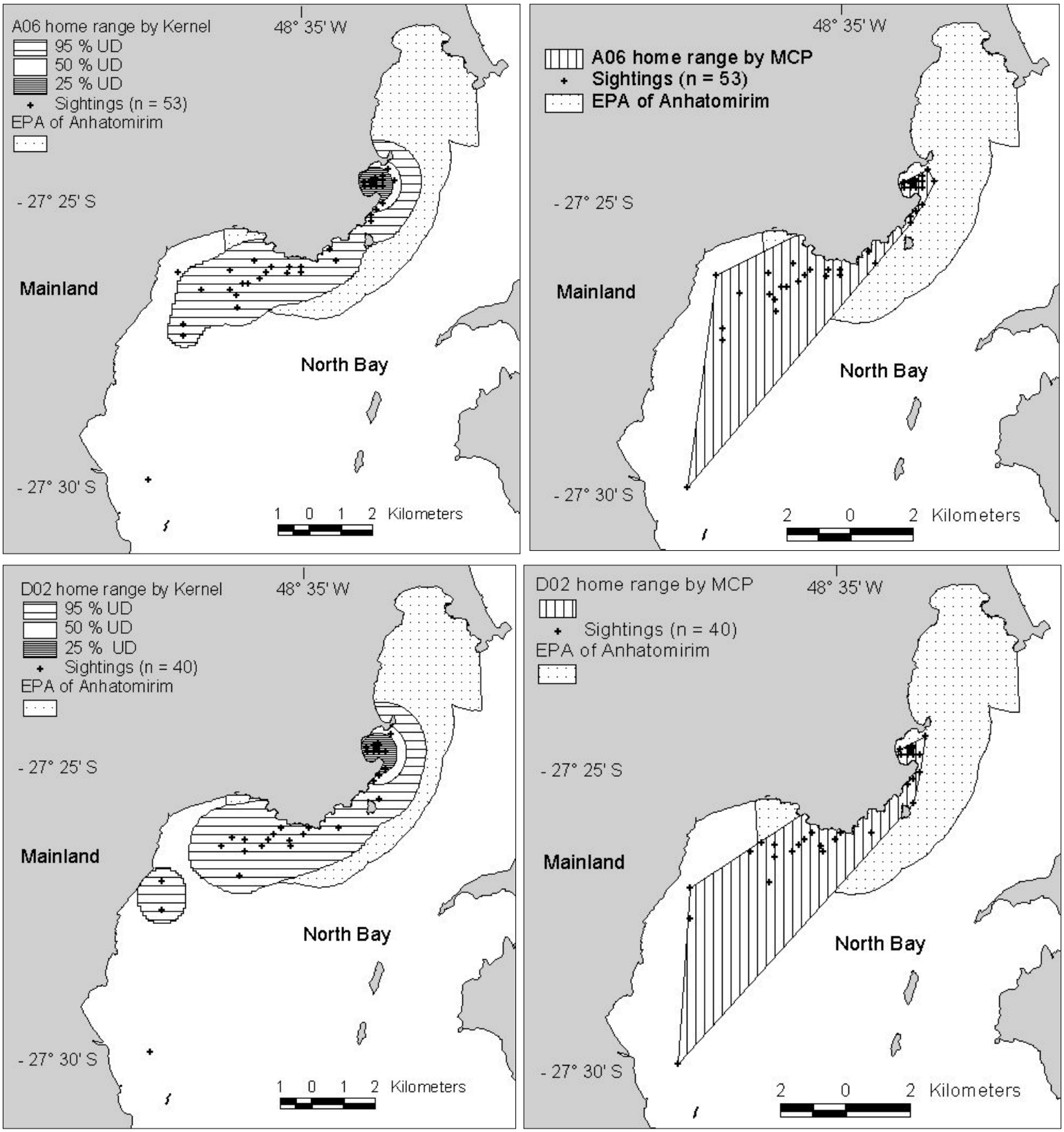

Figure 6. Home ranges of two marine tucuxis (\#A06 - top, and D02 - 'probable male', bottom) in Baía Norte, southern Brazil, calculated by the kernel (left) and the minimum convex polygon (MCP - right) methods. 
(Flores, 2003) and stable individual associations (Flores, unpublished). Such characteristics combined with the home range results presented here have implications for various conservation issues, which are discussed later.

\section{Movement patterns}

The results presented here for distance traveled and rate of movement, should be considered underestimates, because it was not possible to follow marine tucuxis throughout $24 \mathrm{~h}$ periods and all combined data were used regardless the activity pattern (travelling, feeding, feeding/travelling, socializing and resting) or diurnal variation in activity.
However, distance moved or traveled in a day reached its maximum value of $29.97 \mathrm{~km}$. This is comparable to coastal bottlenose dolphins. Bottlenose dolphins daily distance moved or traveled varies with study site and techniques applied. Satellite or radio tagged individuals may range up to $30 \mathrm{~km}$ a day (e.g., Mate et al., 1995; Irvine et al., 1981) while individuals tracked from theodolite only during daylight hours ranged $73 \mathrm{~km}$ (Würsig and Würsig, 1979).

Several factors may influence the higher values found for distance moved and daylight rate of movement in winter and autumn (winter mean $=6.49 \mathrm{~km}, \mathrm{SD}=5.21$ and autumn mean $=6.69 \mathrm{~km}, \mathrm{SD}=5.41$; winter: mean $=2.93 \mathrm{~km}, \mathrm{SD}=$ 1.54 and autumn: mean $=2.56 \mathrm{~km}, \mathrm{SD}=1.30$, respectively).
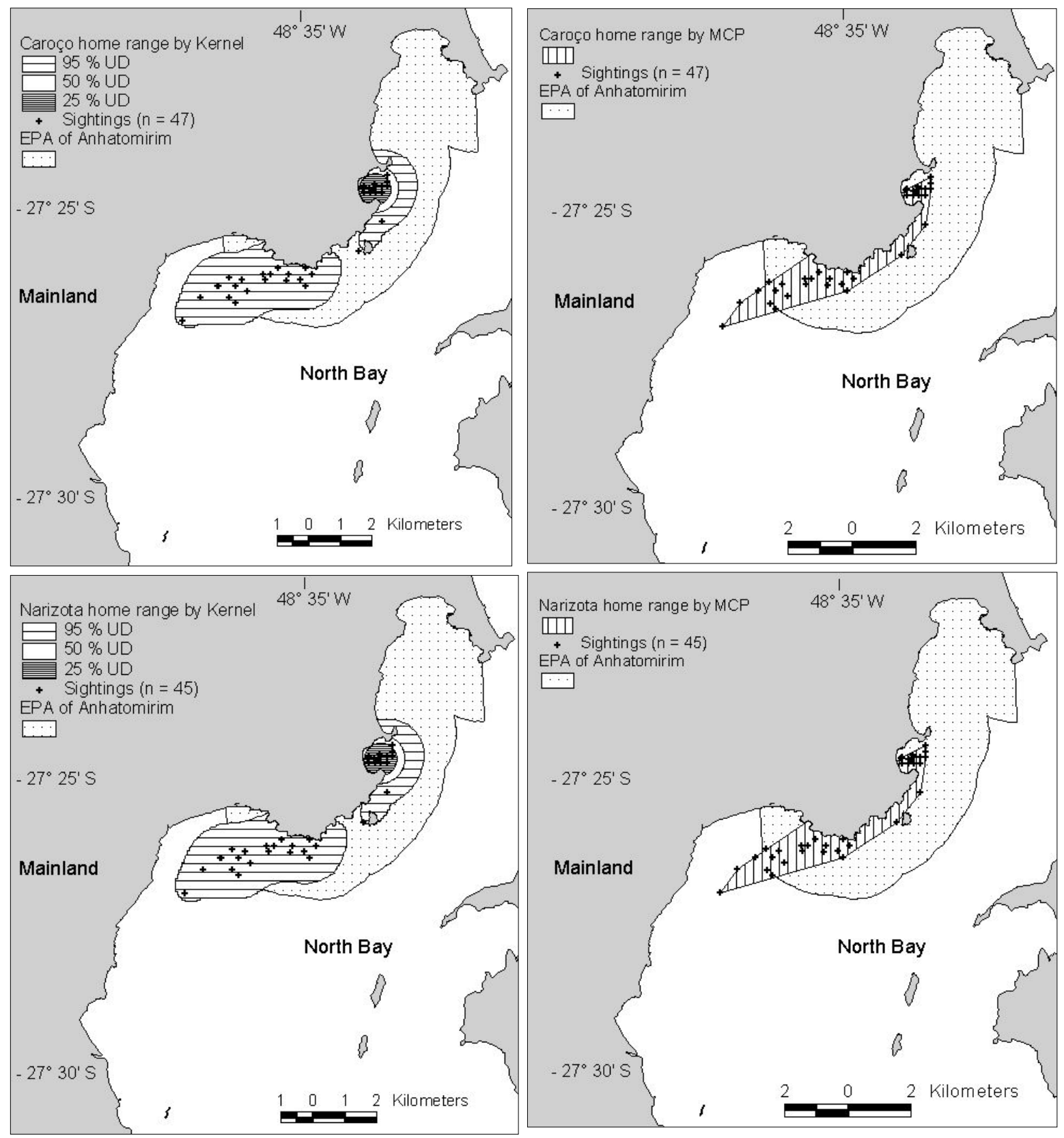

Figure 7. Home ranges of two 'probable male' marine tucuxis ('Caroço' - top, and 'Narizota' - bottom) in Baía Norte, southern Brazil, calculated by the kernel (left) and the minimum convex polygon (MCP - right) methods. 
These probably include prey availability (patterns of distribution, occurrence and schooling), marine tucuxi energetic demand to maintain body temperature, and boat traffic. Tucuxis have been seen feeding (chasing, capturing and even tossing fish in the air) on white mullet (Mugil curema), quite often during autumn and winter while preying frequently on southern anchovy (Lycengraulis grossidens) in summer and spring (P.A.C.Flores, pers.obs.). Various prey items of marine tucuxis including the white mullet and the southern anchovy are found in different numbers in some parts of Baía Norte, thus suggesting seasonality in occurrence (CEPSUL - IBAMA, 1998; UNIVALI, 2001, 2002). Therefore, seasonal variation in the marine tucuxi diet could be expected, though no data are available at this time as the scarce information comes from only four stomach contents (Emerim, 1994). Furthermore, the white mullet is larger and faster than the southern anchovy, which indeed form larger schools. If prey items are patchy and/or scarce and even faster or more difficult to catch, tucuxis might have to move longer distances. Tucuxis in Baía Norte spend more of their daily activity time in traveling or feeding/traveling during winter and autumn than expected and the activity/movement ratio is higher during these seasons as well (Bazzalo and Flores, unpublished data). These factors are likely to affect marine tucuxi feeding success and foraging time and detailed
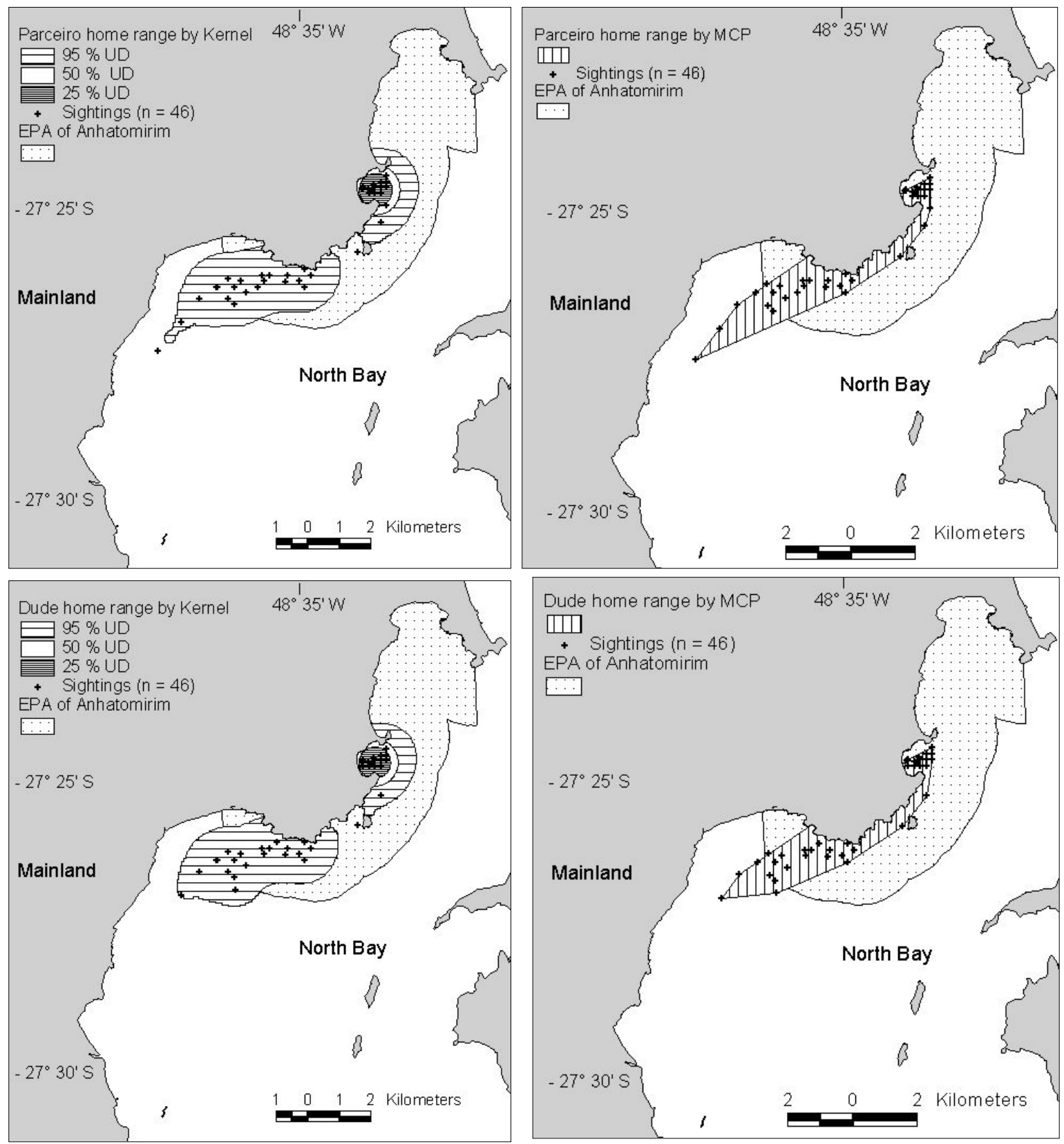

Figure 8. Home ranges of two 'probable male' marine tucuxis ('Parceiro' - top, and 'Dude' - bottom) in Baía Norte, southern Brazil, calculated by the kernel (left) and the minimum convex polygon (MCP - right) methods. 
studies on marine tucuxi feeding habits and prey item abundance, distribution and nutritional value would contribute to understanding of movement patterns of tucuxis in Baía Norte.

Boat traffic increases greatly during summer (Pereira, 2004), the season during which marine tucuxis demonstrated the lowest values for both distance moved $($ mean $=3.72 \mathrm{~km}, \mathrm{SD}=4.7)$ and rate of movement $($ mean $=$ $1.38 \mathrm{~km} / \mathrm{h}, \mathrm{SD}=1.32$ ). Besides the regular fishing and tourism boats, summer brings countless other tourism, speed, sailing and inflatable boats as well as wave runners and jet skies. Whether such high levels of boat traffic create physical and acoustic barriers shrinking the area available for dolphins is unknown. Disturbance responses for tucuxi relative to boats in Baía Norte have been demonstrated during data collected from 1993 to 2003 (Pereria, 2004). From 665 boat-dolphins encounters recorded, $64.3 \%$ ( $\mathrm{n}=$ 428) caused negative responses, defined as interruption and change in previous surface behavior due to the boat approach (Pereira, 2004). Furthermore, the vast majority of encounters occurred in summer and dolphins' responses were affected be season, boat type and boat approach (Pereira, 2004). In Baía Norte, daily movement and activity cycles show that in summer, marine tucuxis tend to spend much more time in and nearby their core areas where probably physiographical and ecological factors favor protection and food gathering at the same time (Bazzalo and Flores, unpublished data).

Tucuxi movement patterns clearly follow the 3m-depth contour usually parallel to the coastline. Bottlenose dolphins in Golfo de San Jose, Argentina, likely use the 5m depth contour as a guidance lane (Würsig and Würsig, 1979) and it is likely that tucuxis in Baía Norte may use the $3 \mathrm{~m}$ depth contour in the same way. All movements from the North and South sectors of the home range were undertaken in the same area between Anhatomirim Is. and mainland, thus enhancing the importance of this pathway (Fig. 10).

This study presents the first data on marine tucuxi home range and movement patterns. These findings must be viewed with caution, however, as 'conclusions based on short-term data tend to be transitory and simplistic' (Scott et al., 1990). The continuation and even refinement of our studies is then extremely important, not just because the subject is long living and has low reproductive rate (Ramos et al., 2000; Rosas and Monteiro-Filho, 2003; Santos et al., 2003) but also as the studied population is discrete and resident with high site fidelity to the area (Flores, 1999; 2003).

\section{Conservation implications}

The studied population of marine tucuxi was given specific protection in May 1992 through the creation of the Environmental Protection Area of Anhatomirim (Federal Decree \# 528 of 20 May 1992). The limits of this open-use, protected area were defined with the very preliminary knowledge on distribution and movements available at that time from systematic observations using fixed observation points on land and few boat surveys (Flores, 1992) as well as opportunistic observations (Simões-Lopes, 1988). Later regulations in January 1998 applied boat traffic restrictions in a small sector of the marine tucuxi distribution (Directive 58-N of January 1998) taking into consideration the zones with higher usage by tucuxis from 1993 to 1996 (Flores, unpublished data).

The percentage of marine tucuxi's overall home range within the EPAA could be considered moderate to high
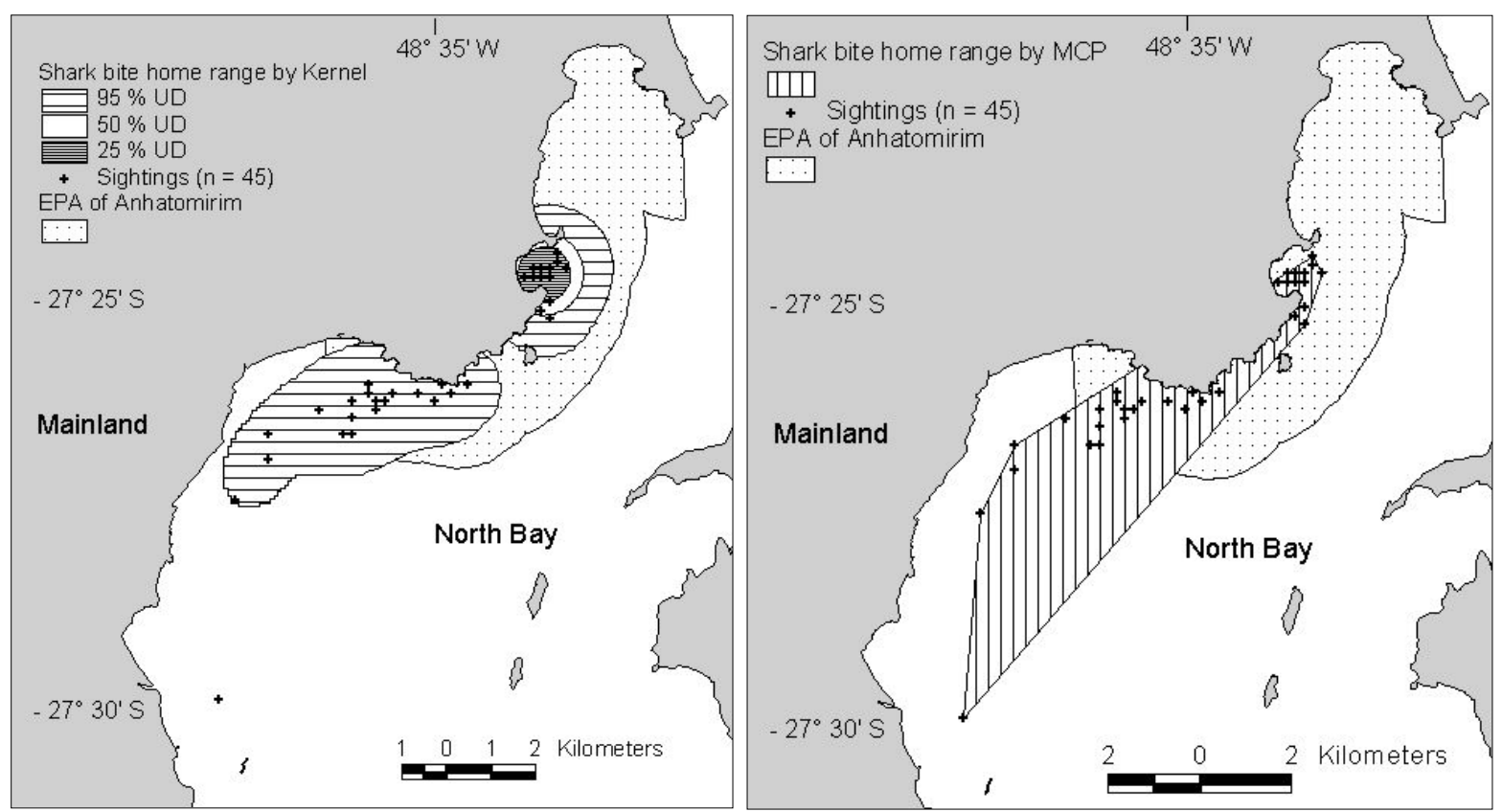

Figure 9. Home ranges of one tucuxi ('Shark Bite' or \#SB) in Baía Norte, southern Brazil, calculated by the kernel (left) and the minimum convex polygon (MCP - right) methods. 
depending on the estimator used $\left(54 \%\right.$ or $5.9 \mathrm{~km}^{2}$ by MCP and $74.71 \%$ or $11.32 \mathrm{~km}^{2}$ using the kernel). Nevertheless, core areas at both the 25 and $50 \%$ UD levels are completely within the EPAA and comprise the 'boat restricted zone' created in 1998. Therefore, the boundaries of the EPAA are instrumental in fulfilling its main goal of helping to protect the marine tucuxi population. These data combined with those presented elsewhere on residency and site fidelity (Flores, 1999; 2003), distribution and occurrence patterns (Flores 2003) indicate that conservation of this
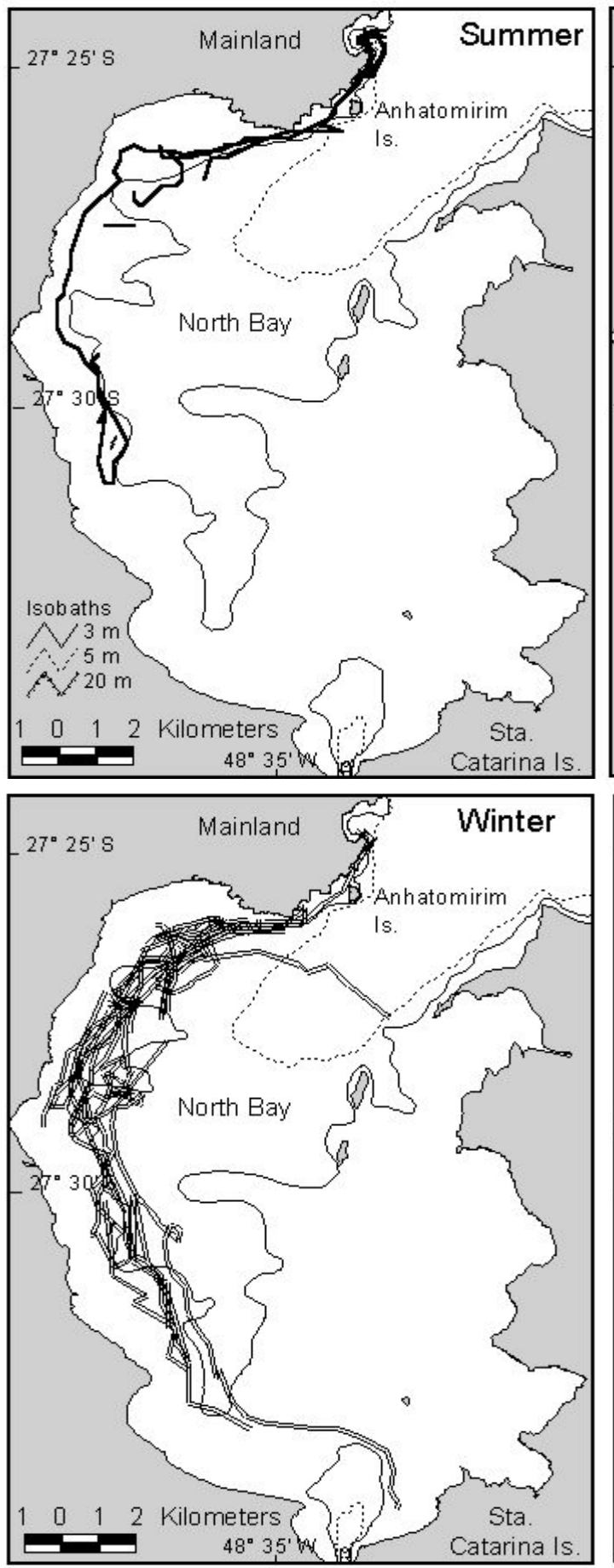

population would be appropriately managed on a small spatial scale over a long term perspective albeit including further practices and regulations. Clearly, conservation efforts would not work properly if existing laws are not strictly respected. Among such important conservation actions we recommend that a buffer zone should be created southward of limits of the protected area. This zone would encompass the overall home range (considering both the MCP and the kernel methods). This will not be effective without the limitation and/or restriction of boat traffic and
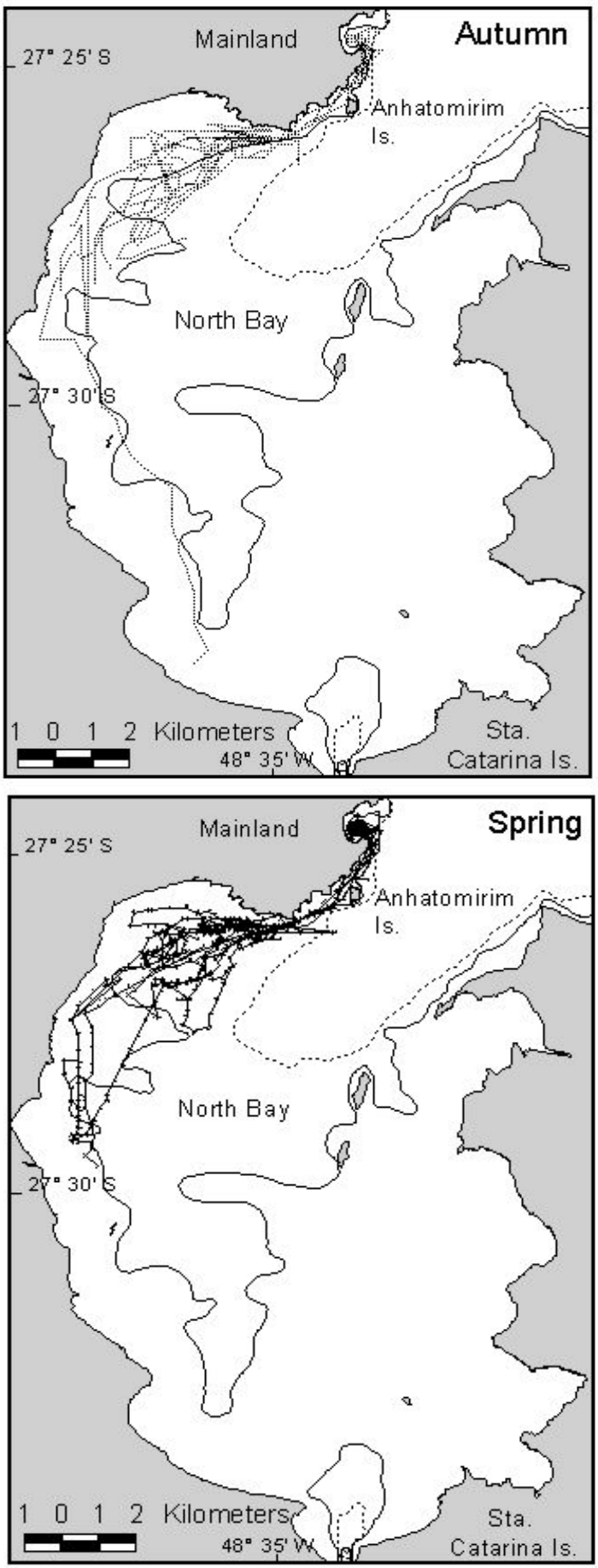

Figure 10. Movement patterns of marine tucuxi (Sotalia fluviatilis) by seasons in Baía Norte, southern Brazil, during 2001 and 2002. 
aquaculture farming in sections of this area within at least the tucuxi core areas both at the 50\% and 25\% UD - where and when regulations are yet not available. Additionally, concomitant with the above, there is a need for constant, adequate enforcement of fishery and boat traffic regulations throughout the protected area as well as the proposed buffer zone.

Incidental mortality in fisheries and ocean pollution have long been considered important threats to cetaceans mainly in coastal habitats (e.g., Twiss and Reeves, 1999; Reeves et al., 2003). Mortality of marine tucuxis have been reported in the study area though no direct assessment has been conducted (Simões-Lopes and Ximenez, 1990; Flores 1992). Also, this impact is known elsewhere in coastal Brazil, being considered the main direct threat to the species in the marine environment (e.g., Siciliano, 1994; Da Silva and Best, 1996; Flores, 2002). More recently, pollutants such as PCBs and heavy metals have been found in low levels in the marine tucuxi (Monteiro-Neto et al. 2003; Yougui et al. 2003). The effects of these factors on marine tucuxis in Baía Norte also deserve attention and further studies. The southern area of Baía Norte has more urban development and sewage discharge from domestic, incipient industries and agricultural outfalls than in the dolphin's home range. Organic substances and heavy metals are not a major problem in the bay yet (Silva et al., 1996; Cerutti and Barbosa, 1997) but high bacterial contamination was found in two locations in the

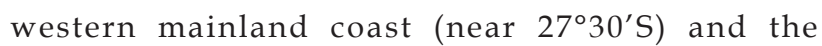
southernmost sector of the study area (Cerutti and Barbosa, 1997). Considerable levels of heavy metals including arsenic, lead, and selenium were found in the water and sediments at the very South sector of Baía Norte and in its mangroves (Queiróz et al., 1993; Silva et al., 1996). A decreasing gradient of contamination of these metals was found from the south to the north in the locations assessed (Silva et al., 1996). However no signs of such metals were present in mullets (Mugil spp.) studied in the southern sector of the bay and the mangrove located near the major urban development (Benatto, 1999). This may indicate either the efficiency of mangroves in retention of such pollutants (Queiróz et al., 1993) or a need of further and more detailed analysis on fishes as well as other animals (Benatto, 1999). Combining studies on these aspects with the continuation of the research on the tucuxis together with biopsy of individuals already underway will contribute even further to their conservation.

\section{Acknowledgments}

Funds to our long-term program on the ecology and protection of the marine tucuxi came from various sources and we deeply thank International Wildlife Coalition, Earthwatch Institute, Cetacean Society International, Whale and Dolphin Conservation Society and Fundação O Boticário de Proteção à Natureza. Other grants were donated by Sociedade de Pesquisa e Educação Ambiental (Brasil), The
Humane Society of the United States, the Society for Marine Mammalogy and IdeaWild (USA). PACF deeply thanks the Whale and Dolphin Conservation Society and Cetacean Society International for early funding which allowed the beginning of boat surveys and photoidentification in 1993 specially to Alison Smith (WDCS) and Bill Rossiter (CSI) for all support and stimulation. A scholarship from the Conselho Nacional de Desenvolvimento Científico e Tecnológico (CNPq Proc. 146609/1999-9) during 1999/2003 to PACF was greatly appreciated. The dedicated interns and Earthwatch Institute volunteers helped to conduct fieldwork and data entry in 2001/02. Logistical support since 2002 has been provided by Aquaculture Laboratory at Sambaqui, Universidade Federal de Santa Catarina. Edward C.G. Owen kindly provided help in using ArcView extensions. PACF wishes to express deep appreciation to Nelson F. Fontoura (Laboratório de Dinâmica Populacional, PUCRS), Paulo H. Ott (Gemars and Feevale, Brazil), Salvatore Siciliano (Laboratório de Ecologia, ENSP/Fiocruz, Brazil) and Randall S. Wells (Conservation Biology Department, Chicago Zoological Society, c/o Mote Marine Laboratory, USA) who served on his Ph.D. thesis committee and commented on earlier drafts of this manuscript. We thank Thomas A. Jefferson for kindly and thoroughly reviewing the final manuscript.

\section{References}

Andrade, L., Siciliano, S. and Capistrano, L. (1987) Movimentos e atividades do boto Sotalia guianensis (Cetacea, Delphinidae) na Baía de Guanabara, Rio de Janeiro. Pages 71-74 in Anais da $2^{a}$ Reunião de Trabalho de Especialistas em Mamíferos Aquáticos da América do Sul, Rio de Janeiro, Brasil, Fundação Brasileira para a Conservação da Natureza.

Aveline, L.C. (1980) Fauna dos manguezais brasileiros. Revista Brasileira de Geografia 42: 786-821.

Bigg, M.A., Olesiuk, P.F., Ellis, G.M., Ford, J.K.B. and Balcomb, K.C. III. (1990) Social organization and genealogy of resident killer whales (Orcinus orca) in coastal waters of British Columbia and Washington State. Reports of the International Whaling Commission (Special Issue 12) 383-405.

Bittencourt, M.L. (1983) Orcinus orca "baleia assassina" (Cetacea, Delphinidae) primeiro registro para o litoral norte catarinense, com notas osteológicas. / Orcinus orca "killer whale" (Cetacea, Delphinidae) first Record for the north shore of Santa Catarina State Brazil, with osteological notes. Arquivos de Biologia e Tecnologia 26: 77-102.

Borobia, M., Siciliano, S., Lodi, L. and Woek, W. (1991) Distribution of the South American dolphin Sotalia fluviatilis. Canadian Journal of Zoology 69: 1025-1039.

Borobia, M. and Barros, N.B. (1989) Notes on the diet of marine tucuxi Sotalia fluviatilis. Marine Mammal Science 5: 395-399.

Burt, W.H. 1943. Territoriality and home-range concepts applied to small mammals. Journal of Mammalogy 24: 346-352.

CEPSUL-IBAMA (1998) Informe da pesca extrativa marinha em Santa Catarina de 1995 a 1996. Instituto Brasileiro do Meio Ambiente e dos Recursos Naturais Renováveis - Centro de Pesquisa e Extensão Pesqueira das Regiões Sul e Sudeste, Itajaí, SC, Brazil.

Cerutti, R.L. and Barbosa, T.C. (1997) Contaminação bacteriana das águas superficiais da Baía Norte, Ilha de Santa Catarina, SC. Aquitaine Ocean 3: 59-64.

Cintrón, G. and Schaeffer-Novelli, Y. (1983) Introducción a la ecologia del manglar. UNESCO-ROSTLAC, Montevideo, Uruguay. 
Clezar, L., Hostim-Silva, M. and Ribeiro, G.C. (1998) Comunidade de peixes do manguezal de Itacorubi, Ilha de Santa Catarina, SC, Brasil. Pages 205-216 in Soriano-Sierra, E.J. and Sierra de Ledo, B. (Eds) Ecologia e Gerenciamento do Manguezal de Itacorubi. Nemar/ CCB/UFSC and SDM/FEPEMA, Florianópolis, SC, Brazil.

Connor, R.C. (2000) Group living in whales and dolphins in Mann, J., Connor, R.C., Tyack, P. L. and Whitehead, H. (Eds) Cetacean Societies: Field Studies of Dolphins and Whales, pp.199-218. University of Chicago Press, Chicago, II.

Cremer, M.J. (2000) Ecologia e conservação do golfinho Sotalia fluviatilis guianensis (Cetacea: Delphinidae) na Baía de Babitonga, litoral Norte de Santa Catarina. M.Sc. Thesis, Universidade Federal de São Carlos, São Carlos, Brazil. 226pp.

Da Silva, V.M.F. and Best, R.C. (1996) Sotalia fluviatilis. Mammalian Species 527: 1-7.

Di Beneditto, A.P.M. (2000) Ecologia Alimentar de Pontoporia blainvillei e Sotalia fluviatilis (Cetacea) na costa norte do estado do Rio de Janeiro, Brasil. Doctoral Thesis, Universidade Estadual do Norte Fluminense, Campos dos Goytacazes, Brazil. 173pp.

Emerim, E.G. (1994) Contribuição para o conhecimento dos hábitos alimentares de delfinídeos (Mammalia, Cetacea, Odontoceti, Delphinidae) nas proximidades da Ilha de Santa Catarina, SC, Brasil. B.Sc. Monography, Universidade Federal de Santa Catarina, Florianópolis, Brazil. 45pp.

Flores, P.A.C. (1992) Observações sobre movimentos, comportamento $e$ conservação do golfinho ou boto Sotalia fluviatilis (Gervais, 1853) (Mammalia-Cetacea-Delphinidae) na Baía Norte de Santa Catarina, SC, Brasil. B.Sc. Monography, Universidade Federal de Santa Catarina, Florianópolis, Brazil. 48pp.

Flores, P.A.C. (1999) Preliminary results of a photoidentification study of the marine tucuxi Sotalia fluviatilis in southern Brazil. Marine Mammal Science 15: 840-847.

Flores, P.A.C. (2002) Tucuxi (Sotalia fluviatilis) in Perrin, W.F., Würsig, B. and Thewissen, J.G.M. (Eds) Encyclopedia of Marine Mammals, pp.1267-1269. Academic Press, San Francisco.

Flores, P.A.C. (2003) Ecology of the marine tucuxi (Sotalia fluviatilis) in southern Brazil. Ph.D. Dissertation, Pontifícia Universidade Católica do Rio Grande do Sul, Porto Alegre, Brazil. 141pp.

Flores, P.A.C., Sousa-Lima, R.S. and Siqueira, G.S. (2000) Avistagens de franciscana (Pontoporia blainvillei) na Baía Norte, Santa Catarina, Sul do Brasil. Pages 71-74 in Report of the Third Workshop for Coordinated Research and Conservation of the Franciscana Dolphin (Pontoporia blainvillei) in the Southwestern Atlantic. United Nations Environmental Program/Convention on the Migratory Species, Bonn, Germany. [Available through UNEP/CSM Secretariat, Martin Luther King St. 8, 53175, Bonn, Germany]

Forcada, J. (2002) Distribution in Perrin, W.F., Würsig, B. and Thewissen, J.G.M. (Eds) pages 327-333 in Encyclopedia of Marine Mammals. Academic Press, San Francisco.

Ford, J.K.B., Ellis, G.M. and Balcomb, K.C. III. (1994) Killer Whales: the natural history and genealogy of Orcinus orca in British Columbia and Washington State. University of British Columbia Press, Vancouver, Canada.

Harris, S., Cresswell, W. J., Forde, P. G., Trewhella, W. J., Woollard, T. and Wray, S. (1990) Home-range analysis using radio-tracking data - a review of problems and techniques particularly as applied to the study of mammals. Mammal Review 20: 97-123.

Hayne, D.W. (1949) Calculation of size of home range. Journal of Mammalogy 30: 1-18.

Hostim-Silva, M., Ribeiro, G.C., Clezar, L. and Sierra de Ledo, B. (1998) Abundância relativa e distribuição espaço-temporal de Micropogonias furnieri (Desmarest) e Cynoscion leiarchus (Cuvier) (Perciformes, Scianidae) no manguezal de Itacorubi, Santa Catarina, Brasil. Pages 247-258 in Soriano-Sierra, E.J. and Sierra de Ledo, B. (Eds) Ecologia e Gerenciamento do Manguezal de Itacorubi. Nemar/CCB/UFSC and SDM/FEPEMA, Florianópolis, SC, Brazil.
Hung, S.K. and Jefferson, T.A. (2004) Ranging patterns of IndoPacific humpback dolphins (Sousa chinensis) in the Pearl Harbor River, People's Replubic of China. Aquatic Mammals 20: 159-174.

Irvine, A.B., Scott, M.D., Wells, R.S. and Kaufmann, J.H. (1981) Movements and activities of the Atlantic bottlenose dolphin, Tursiops truncatus, near Sarasota, Florida. Fishery Bulletin 79: 671-688.

Jenrich, R.I. and Turner, F.B. (1969) Measurement of non-circular home range. Journal of Theoretical Biology 22: 227-237.

Lusseau, D., Schneider, K., Boisseau, O.J., Haase, P., Slooten, E. and Dawson, S.M. (2003) The bottlenose dolphin community of Doubtful Sound features a large proportion of long-lasting associations: Can geographic isolation explain this unique trait? Behavioral Ecology and Sociobiology 54: 396-405.

Marcon, E.H. (2000) Comunidade ictícia do estuário do rio Ratones, Florianópolis, SC, Brasil. B.Sc. Monography, Universidade Federal de Santa Catarina, Florianópolis, SC. 73pp.

Mate, B.R., Rossbach, K.A., Nieukirk, S.L., Wells, R.S., Irvine, A.B., Scott, M.D. and Read, A.J. (1995) Satellite-monitored movements and dive behavior of a bottlenose dolphin (Tursiops truncatus) in Tampa Bay, Florida. Marine Mammal Science 11: 452-463.

Meffe, G.K., Caroll, C.R. and contributors. (1997). Principles of Conservation Biology. $2^{\text {nd }}$ edition, Sunderland, MA, Sinauer Associates, Inc. $729 \mathrm{pp}$.

Monteiro-Neto, C., Itavo, R.V. and Moraes, L.E.S. (2003) Concentrations of heavy metals in Sotalia fluviatilis (Cetacea: Delphinidae) off the coast of Ceará, northeast Brazil. Environmental Pollution, 123: 319-324.

Norris, K. S., Würsig, B., Wells, R. S. and Würsig, M. (1994) A Spinner Dolphin's Bay. Pages 66-102 in Norris, K. S , Würsig, B., Wells, R. S. and Würsig, M. (Ed.) The Hawaiian Spinner Dolphin. University of California Press, Berkeley, California.

Owen, E.C.G., Wells, R.S. and Hofmann, S. (2002). Ranging and association patterns of paired and unpaired adult male Atlantic bottlenose dolphins, Tursiops truncatus, in Sarasota, Florida, provide no evidence for alternative male strategies. Canadian Journal of Zoology 80: 2072-2089.

Pereira, M.G. (2004) Reações comportamentais de Sotalia fluviatilis (Cetacea: Delphinidae) em encontros com embarcações na Baía Norte de Santa Catarina. B.Sc. Monograph, Departamento de Biologia, Universidade Federal de Santa Catarina, Florianópolis. 66pp.

Queiróz, R.R.U., Stadler, E., Ledo, B.S., Soriano-Sierra, E.J. and Haas, P. (1993) Heavy metal pollution of Santa Catarina Island. Pages 3326-3333 in Magoon, O.T., Wilson, W.S., Converse, H. and Tobin, L.T. (Eds) Brazil Coastal Zone '93: Proceedings of the Eight Symposium on Coastal and Ocean Management, New Orleans, USA.

Reeves, R.R., Smith, B.D., Crespo, E.A. and Notarbartolo di Sciara, G. (2003) Dolphins, Whales and Porpoises: 2002-2010 Conservation Action Plan for the World's Cetaceans. IUCN-The World Conservation Union, Gland, Switzerland. 139pp.

Ribeiro, G.C., Clezar, L., Hostim-Silva, M. and Sierra de Ledo, B. (1998) Ocorrência, abundância e distribuição de jovens de Mugilidae no manguezal de Itacorubi, Santa Catarina, Brasil. Pages 259-268 in Soriano-Sierra, E.J. and Sierra de Ledo, B. (Eds) Ecologia e Gerenciamento do Manguezal de Itacorubi. Nemar/CCB/UFSC and SDM/FEPEMA, Florianópolis, SC, Brazil.

Samuel, M.D. and Fuller, M.R. (1996) Wildlife radiotelemetry. Pages 370-418 in Bookhout, T.A. (Ed.) Research and Management Techniques for Wildlife and Habitats. The Wildlife Society, Maryland, USA.

Santos, M.C. de O., Rosso, S., Santos, R.A., Lucato, S.H.B. and Bassoi, M. (2002) Insights on small cetacean feeding habits in southeastern Brazil. Aquatic Mammals 28: 38-45. 
Santos, R.A. and Haimovici, M. (2001) Cephalopods in the diet of marine mammals stranded or incidentally caught in southeastern and southern Brazil $\left(21-34^{\circ} \mathrm{S}\right)$. Fisheries Research 52: 99-112.

Scott, M.D., Wells, R.S. and Irvine, A.B. (1990) A long-term study of bottlenose dolphins on the west coast of Florida. Pages 235244 in Leatherwood, S. and Reeves, R.S. (Eds) The Bottlenose Dolphin. Academic Press, San Diego, USA.

Seaman, D.E. and Powell, R.A. (1996) An evaluation of the accuracy of kernel density estimators for home range analysis. Ecology 77: 2075-2085.

Seaman, D.E., Millspaugh, J.J., Kernohan, B.J., Brundige, G.C., Raedeke, K.J. and Gitzen, R.A. (1999) Effects of sample size on kernel home range estimates. Journal of Wildlife Management 63: 739-747

Silva, M.R. da, Lamotte, M., Donarde, F.X., Soriano-Sierra, E.J. and Robert, M. (1996) Metal contamination in surface sediments of mangroves, lagoons and southern bay in Florianópolis Island. Environmental Technology 17: 1035-1046.

Silverman, B.W. (1986) Density estimation for statistics and data analysis. Chapman and Hall, London, UK.

Simões-Lopes, P.C. (1988) Ocorrência de uma população de Sotalia fluviatilis Grevais, 1853, (Cetacea, Delphinidae) no limite Sul de sua distribuição, Santa Catarina, Brasil. Biotemas 1: 57-62.

Simões-Lopes, P.C. and Ximenez, A. (1990) O impacto da pesca artesanal em área de nascimento do boto cinza, Sotalia fluviatilis (Cetacea, Delphinidae), SC, Brasil. Biotemas 3: 67-72.

Simões-Lopes, P.C. and Ximenez, A. (1993) Annotated list of the cetaceans of Santa Catarina coastal waters, southern Brazil. Biotemas 6: 67-92.

Stone, G.S., Brown, J. and Yoshinaga, A. (1995) Diurnal movement patterns of Hector's dolphin as observed from clifftops. Marine Mammal Science 11: 395-402.

Smolker, R.A., Richards, A.F., Connor, R.C. and Pepper, J.W. (1992) Sex differences in patterns of association among Indian Ocean bottlenose dolphins. Behaviour 123: 38-69.

Tolley, K.A., Read, A.J., Wells, R.S., Urian, K.W., Scott, M.D., Irvine, A.B. and Hohn, A.A. (1995) Sexual dimorphism in wild bottlenose dolphins (Tursiops truncatus) from Sarasota, Florida. Journal of Mammalogy 76: 1190-1198.

Twiss, J.R., Jr. and Reeves, R.R. (1999) Conservation and Management of Marine Mammals. Smithsonian Institution Press, Washington D.C., USA.

UNIVALI (2001) Boletim estatístico da pesca industrial de Santa Catarina ano 2000: ações prioritárias ao desenvolvimento da pesca e aqüicultura no sul do Brazil. Universidade do Vale do Itajaí, Itajaí, SC, Brazil.

UNIVALI (2002) Boletim estatístico da pesca industrial de Santa Catarina ano 2001: ações prioritárias ao desenvolvimento da pesca e aqüicultura no sul do Brazil. Universidade do Vale do Itajaí, Itajaí, SC, Brazil.

Van Winkle, W. (1975) Comparison of several probabilistic homerange models. Journal of Wildlife Management 39: 118-123.

Wells, R.S. (1991) The role of long-term study in understanding the social structure of a bottlenose dolphin community. Pages 199-225 in Pryor, K. and Norris, K.S. (Eds) Dolphin Societies: Discoveries and Puzzles. University of California Press, Berkeley, USA.

White, G.C. and Garrot, R.A. (1990) Analysis of wildlife radio-tracking data. Academic Press, San Diego, USA.

Worton, B.J. (1987) A review of models of home range for animal movement. Ecological Modelling 38: 277-298.

Würsig, B. and Würsig, M. (1979) Behavior and ecology of the bottlenose dolphin, Tursiops truncatus, in the South Atlantic. Fishery Bulletin 77: 399-412.

Yogui, G.T., Santos, M.C.O. and Montone, R.C. (2003) Chlorinated pesticides and polychlorinated byphenils in mairne tucuxi dolphins (Sotalia fluviatilis) from the Cananéia estuary, southeastern Brazil. The Science of the Total Environment 312: 67-78.

Zanelatto, R.C. (2001) Dieta do boto-cinza, Sotalia fluviatilis (Cetacea, Delphinidae), no complexo estuarino da Baía de Paranaguá e sua relação com a ictiofauna de manguezais. M.Sc. Thesis. Universidade Federal do Paraná, Curitiba, Brazil. 125pp.

Zar, J.H. (1999) Biostatistical Analysis, $4^{\text {th }}$ edition, Prentice Hall, Upper Saddle River, USA. 